\title{
Forces Shaping Future U.S. Coal Production and Use
}

More than half of the electricity in the United States is generated by coalfired powerplants. U.S. coal producers sell almost 90 percent of their product for electricity generation, and so, the future of the U.S. coal industry will be determined by the future of coal-fired electricity-generation plants.
The U.S. Geological Survey (USGS) is completing a National Coal Resource Assessment (NCRA) of five major coal-producing regions of the United States (fig. 1): (1) the Appalachian Basin, (2) the Illinois Basin, (3) the Gulf Coast, (4) the Colorado Plateau, and (5) the Northern Rocky Mountains and Great Plains. The Powder River and Williston Basins are the principal producing areas of the Northern Rocky Mountains and Great Plains region.

Two principal forces that will control the size of the coal market for electric power generation are electricity-market deregulation and airborne emissions regulation.

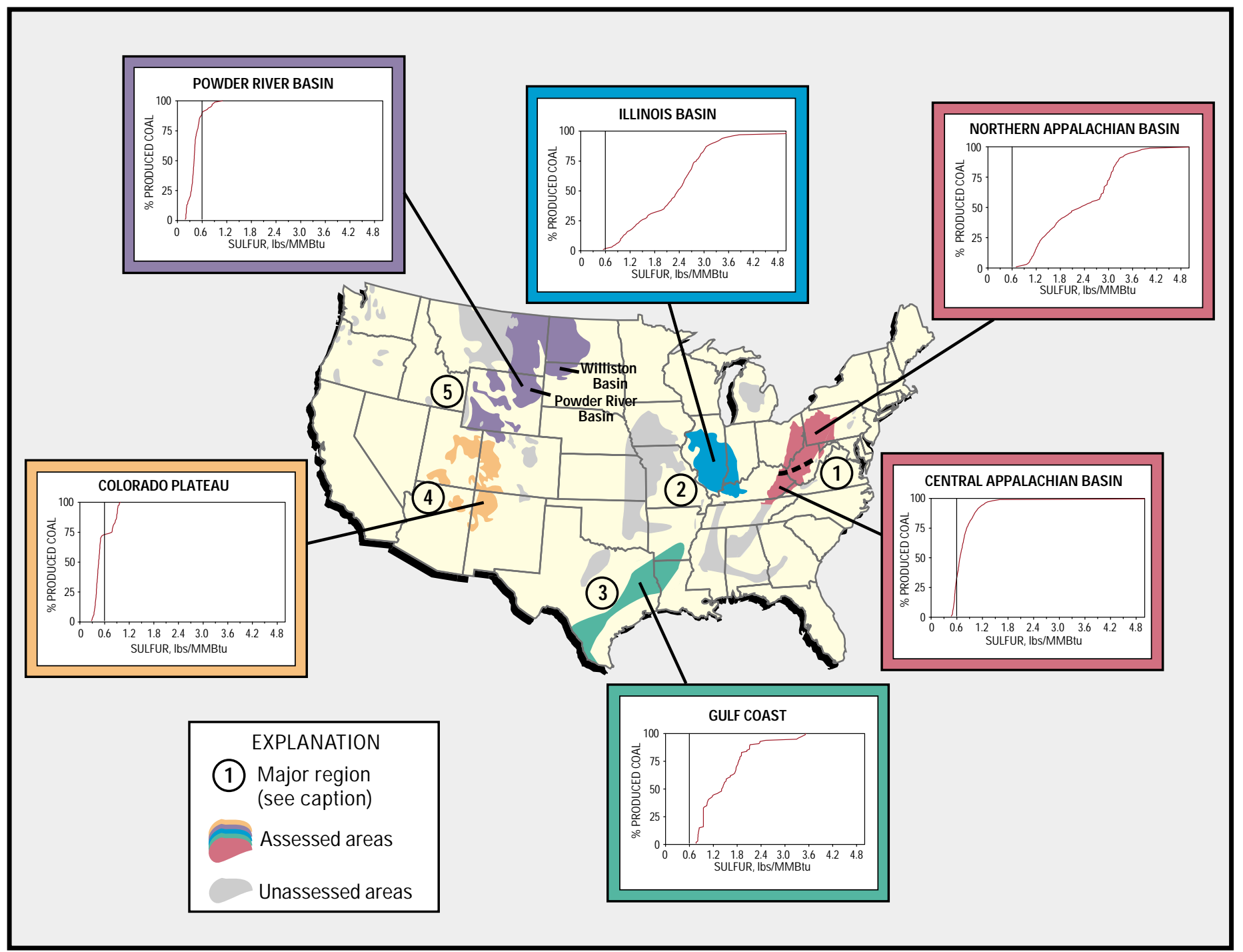

Figure 1. Coal fields of the conterminous United States. The U.S. Geological Survey is completing a National Coal Resource Assessment; colors on the map show assessed areas within five major coal-producing regions: (1) the Appalachian Basin, (2) the Illinois Basin, (3) the Gulf Coast, (4) the Colorado Plateau, and (5) the Northern Rocky M ountains and Great Plains (includes the Pow der River and Williston Basins). Graphs show sulfur contents of coal delivered to powerplants in 1998 from mines in a specific area. Vertical line in each graph is the 2000 Phase II SO $\mathrm{S}_{2}$ compliance standard of the 1990 Clean Air Act Amendments. Data on sulfur contents are from the Federal Energy Regulatory Commission (available at http://w w w.ferc.fed.us/electric/f423/F423annual.htm). $\mathrm{lbs} / \mathrm{M} M \mathrm{~B}$ tu $=$ pounds per million British thermal units of calorific value. 


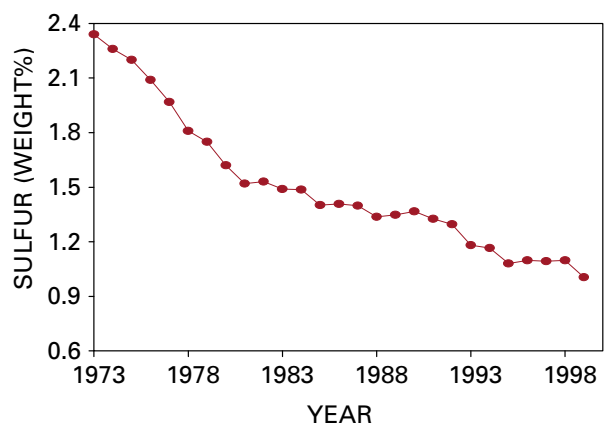

Figure 2. Sulfur content of coals used at U.S. powerplants, 1973 to 1999. Data from the Federal Energy Regulatory Commission (available at http://w w w.ferc.fed.us/electric/ f423/F423annual.htm).

Under market deregulation, electric powerplants will no longer have captive markets but will have to compete to sell their electricity. They will have to search for the lowest cost fuel supplies. The quest to reduce fuel costs has reduced the number of operating coal mines by half since 1990, as smaller, inefficient mines have closed and larger mines have adopted new technologies to increase productivity. At the coal industry level, much of the productive capacity is now concentrated in a handful of major producers. Coal-fired plants also will compete with new, highly efficient, central gas-fired powerplants and "distributed or localized" generation systems including micro-gasturbines and photovoltaic systems that generate electricity.

The other principal force that will shape the coal market is the need to comply with the 1990 Clean Air Act Amendments (CAAA90). The amendments set new Federal regulations on sulfur dioxide $\left(\mathrm{SO}_{2}\right)$ emissions from powerplants. Figure 2 shows declining sulfur contents of coals used by U.S. powerplants from 1973 to 1999.

Phase II of the CAAA90, implemented in January 2000, capped powerplant $\mathrm{SO}_{2}$ emissions nationally at 8.95 million short tons per year. This cap would currently limit a plant's emissions to 1.2 pounds of $\mathrm{SO}_{2}$ per million British thermal units (lbs $\mathrm{SO}_{2} / \mathrm{MMBtu}$ ) (or 0.6 lb sulfur/MMBtu in the coal). Each powerplant is initially allotted $\mathrm{SO}_{2}$ emissions allowances at a rate of $1.2 \mathrm{lbs}$ $\mathrm{SO}_{2}$ /MMBtu based on its fuel use during the 1985 through 1987 base period. Plants constructed after 1996 are not allotted emissions allowances. To keep emissions within the Phase II allotments, an operating coal-fired powerplant that does not currently meet the standard could retrofit with a flue-gasdesulfurization (FGD) system, switch to low-sulfur coal or another fuel, purchase additional emissions allowances, or close down. If a powerplant's emissions are below its initial allotment, it may sell or trade excess allowances. As of January 2000, there were 11.8 million short tons of $\mathrm{SO}_{2}$ allowances available for sale to noncompliant plants; the allowances were accrued during Phase I of the CAAA90.

As of late 1999, responses to industry surveys showed that noncompliant plants anticipated the following changes to achieve compliance:

- plants representing 55 percent of productive capacity would switch to low-sulfur coal

- $\quad$ lants representing 35 percent would purchase $\mathrm{SO}_{2}$ allowances and continue to use higher sulfur coal

- plants representing 10 percent (listed as undecided) would switch to another fuel, shut down boilers, or install FGD systems

The announced intentions to switch to low-sulfur coal could translate into an additional demand for 190 million short tons per year of low-sulfur subbituminous coal or 135 million short tons per year of low-sulfur bituminous coal production. Additional low-sulfur coal demand will increase as the number of stockpiled allowances available for sale to noncompliant plants shrinks.

The graphs in figure 1 show sulfur contents of produced coal transported from mines in a specific area to powerplants in 1998. The vertical line in each graph is the 2000 Phase II $\mathrm{SO}_{2}$ emissions compliance standard. Only small amounts of the coal shipped to powerplants from the northern Appalachian Basin and the Illinois Basin met those emission limits. About 35 percent of the coal shipped from the central Appalachian Basin coal region, 75 percent of the coal shipped from the Colorado Plateau region, and 90 percent of the coal shipped from the Powder River Basin complied with the emissions standard. With coal blending, all of the coal in the Powder River Basin and the Colorado Plateau and 60 percent of the coal shipped from the central Appalachian Basin met compliance limits. Gulf Coast and Williston Basin lignite coals are used at local plants that already have FGD systems. The USGS NCRA estimates that large volumes of low-sulfur coal are in the Powder River Basin and emerging producing regions of the Colorado Plateau.

Provisions of the CAAA90 relating to fine particulates and hazardous airborne pollutants (HAP's) are still planned, and so the full effect of that act has yet to be felt. So far, the forces of deregulation and uncertainty in future emissions rules have shaped power industry responses to the CAAA90 regulations. Projections for the long-term role of coal may be uncertain, but for at least the next decade, it will continue to be the primary indigenous energy source used by the U.S. economy. Knowledge of the quantity and location of potential coal supplies is needed, and a detailed understanding of the quality of the coal will be necessary to meet future energy needs.

\section{For more information, please contact:}

Emil Attanasi

U.S. Geological Survey

956 National Center

Reston, VA 20192

Telephone: (703) 648-6129

E-mail: attanasi@usgs.gov
Brenda Pierce

U.S. Geological Survey 956 National Center

Reston, VA 20192

Telephone: (703) 648-6421

E-mail: bpierce@usgs.gov 